\title{
Effects of Financial Liberalization on the Productivity Growth of Agriculture Sector in the Presence of Structural Breaks: Evidence from Ghana
}

\author{
Robertson Amoah ${ }^{1} \&$ Peter Kwarteng ${ }^{1}$ \\ ${ }^{1}$ Department of Secretaryship and Management Studies, Sunyani Technical University, Ghana \\ Correspondence: Robertson Amoah, Department of Secretaryship and Management Studies, Sunyani Technical \\ University, Ghana. Tel: 233-(0)-548-581-533.
}

Received: February 21, 2020

Accepted: March 23, 2020

Online Published: April 12, 2020

doi:10.5539/ijef.v12n5p22

URL: https://doi.org/10.5539/ijef.v12n5p22

\begin{abstract}
The study examined the relationship between financial liberalization and productivity growth of the Agriculture Sector in Ghana using the annual (yearly) data over the period 1970-2013. In the econometric analysis, the credits provided to private sector, investment, trade liberalization and capital account openness are considered as financial liberalization index while sector level value added as a percentage of GDP represented productivity growth. The stationarity of the series and the long run relationship were analyzed using Zivot-Andrews (1992) and Clemente, Montanes and Reyes (1998) test and Gregory Hansen tests in which structural breaks are considered. The findings of the study revealed that, opening up the economy will yield a positive result of sustainable productivity growth at sector levels. It behooves on the government to ensure that any structural reform programs that are initiated is comprehensively and completely implemented and also accompanied by sound macroeconomic policies to maintained a lasting effect, because the effect of such structural reforms in the long run growth path are prone to be thrown out of gear by other external shocks. The favorable influence of financial liberalization on productivity growth of agriculture sector is confirmed in Ghana. Future studies could be focused on whether financial liberalization will yield the expected effect on agriculture and other economic sectors' productivity growth using primary data from the various sectors of the economy in a survey study.
\end{abstract}

Keywords: financial liberalization, productivity growth, trade liberalization capital account openness, market capitalization, structural breaks

\section{Introduction}

\subsection{Research Background}

The development economists in 1950s and 1960s (Lewis, 1954; Fei \& Ranis, 1961; Jorgenson, 1961) found that agriculture supports other sectors of the economy by means of transfer of surplus from agriculture to non-agriculture sectors. These transfers according the development economic theory can be classified as visible and invisible transfers. Visible transfers, among others are the agricultural trade surplus. This has over the years been the main source of the foreign exchange that developing countries need to finance imported capital and intermediate goods needed to feed the non-agricultural sectors. The invisible transfers on the other hand are the surplus transferred from agriculture to non-agriculture in the form of decline in domestic prices of agricultural produce, resulting from productivity growth improvement of the agricultural sector.

In view of the important place occupied by the agriculture sector in Ghana, the Food and Agriculture Organization (FAO) and the Government have made some major efforts to facilitate the development of policies and strategies that have the potential to sustain the development of the agriculture sector and the natural environment. The rationale behind this is essentially the need to contribute to the enrichment of livelihoods and the development of the economy as a whole. This has been done by strengthening the capacity of national systems and institutions to initiate evidence based strategies and policies which when implemented will drive the needed transformation in the country. There is no doubt that Ghana is still an agrarian economy; the sector's share of GDP is 40 percent representing three quarters of export earnings. Agriculture sector also employs 55 percent of the labor force. Agricultural growth in Ghana is known to be increasing at a faster rate than the non-agricultural sectors with an average growth rate of 5.5 percent, and 5.2 percent for the country as a whole 
(Bogetic et al., 2007).

In recent times, the role of agriculture as the mainstay and driver of economic growth of the economy has been recognized through government initiated policies to increase investment in food and agricultural production. Among these policies and plans are: "The 2018-2021 Ghana Agricultural Investment Plan; the Sustainable Management of Shea Parklands Strategy; the Agricultural Engineering Policy; the Antimicrobial Resistance Policy and Strategy; the Food Safety Policy; the Nutrition Policy; the Seed Policy; the Veterinary and Livestock Improvement Acts; Fisheries legislation and policies; Forest resources governance as part of the drive to launch forest Law Enforcement, Governance and Trade (FLEGT) licenses; and the National Plan of Action against illegal, unreported and unregulated fishing". In view of the poor incomes and employment prospects for the majority of youths and rural dwellers, the government has been working to enhance opportunities for productive employment through programs such as "Planting for Food and Jobs" and "One District on factory"(FAO, 2018).

Regarding agriculture activities in Ghana, land, labor, capital, and management of water resource constitute the main physical inputs that are mostly applied in production; technological and efficiency variabilities are the major reforms in the financial sector initiated to promote effective and efficient mobilization of funds in the agricultural sector. Dabla-Norris et al. (2013) lend credence to the fact that for a country to boost technological catch up, structural reform programs that are specially designed to promote agricultural productivity growth must be initiated and implemented.

The success story of Ghana has been attributed to reforms in the financial sector which is known to facilitate economic growth in both developed and developing economies most especially if it is developed and healthy. This implies that effective and timely reforms policies in the financial sector have the potential to enhance investment and growth in any of the economics sectors including agriculture.

\subsection{Research Motivation/Problem}

Even though there has not been any argument that explicitly condemns the promotion of agriculture, there are scholars and economic policy makers who hold some doubts about the sector's ability to drive economic growth and transformation. That notwithstanding, the recent sharp increases in global food prices points to the urgency of the need to explore deeply our knowledge about the role of agriculture and the means through which the sector could be supported. Besides this, agriculture sector is known to support growth in other sectors such as manufacturing and service sectors by means of both visible and invisible transfers. The period between 2006 and 2015 witnessed an amounts of close to 8,000 billion cedis which represents 12.9 percent rise in GDP as an explicit measure of surplus transferred from agriculture to the other sectors in Ghana. The prospects of the country to take advantage of emerging opportunities will require the country to upgrade agricultural competitiveness, recapture its domestic market shares and above all expand international market shares. The onus is therefore on the government to introduce evidence based agricultural and some other policies and appreciable investment in the sector to enhance agricultural productivity so as to be able to close the existing gaps between current and achievable yields. The recent debate on Ghana's successful agricultural growth of an average growth rate of 5.5 percent even though engendered excitement about the agriculture sector's regenerated potential for becoming the engine of growth in Ghana, critics have however hinted that the recent agricultural growth achieved by the country has essentially been as the result of favorable weather conditions, improved world market prices of agriculture products and also heavily driven by farm land expansion and therefore the high growth rates are not on the basis of improvement in the sector's productivity growth. To that extent we can say that these recorded growth patterns will not be sustainable in the event of any changes in the external conditions that are responsible for the current growth patterns.

Successive Governments of Ghana have dedicated appreciable efforts to facilitate the implementations of programs, policies and strategies to promote sustainable development of the agriculture sector. Among such programs and policies are the structural and economic reforms programs which were intended to realize the associated benefits that are driven by well-developed, effective and efficient financial system. However, in the case of Ghana, according to Jedwab and Osei (2012) is on the contrary because they found that structural reforms implemented in Ghana have neither been growth-enhancing nor growth-reducing.

In the West African sub-region and particularly in Ghana, little effort has been made to conduct studies that specifically dwell on the need to investigate the productivity growth influence of financial liberalization on agriculture sector (Djokoto, 2013). Most of the studies already done in Ghana concentrated on the effects that structural reforms has on the Agricultural growth in general neglecting the main channel of growth that is total factor productivity(TFP) and capital accumulation. Findings from prior studies have indicated that due to the dynamics of the intrinsic characteristics of various sectors, the respective responses of the two main channels of 
growth to the liberalization processes may present different outcomes. This is due to the fact that the effects of financial liberalization are found to be sector-specific or more precisely differ in its impact on the various channels of growth (Gehringer, 2014).

Among the few studies conducted in Ghana, for instance; Djokoto (2013) investigated the effects of financial liberalization on the agricultural output growth, Karikari (1992), Gyapong and Karikari (1999), Frimpong and Oteng-Abayie (2008), and Sakyi (2011) provided empirical evidence for Ghana's economy as a whole on the relationship between financial liberalization and economic performance, while Adenutsi (2008) documented empirical evidence of impact of financial liberalization on industrial performance in Ghana. However, any of the above studies failed to account for the theoretical implications of structural breaks and shocks on the real output of the Ghanaian economy. Similarly, Polat et al. (2013) found that anticipated values of real output that do not take into account the effects of structural breaks and shocks might be affected by errors, and therefore not reliable.

This study is therefore intended to investigate the effects of financial liberalization on productivity growth of the Agricultural sector as measured by total factor productivity (TFP) in the presence of structural breaks.

\subsection{Research Questions}

The research design adopted for this study is quantitative and therefore the research Questions are as follows:

1) Is there a short-run effect of financial liberalization on the productivity growth of the Agricultural Sector.?

2) Is there a long-run effect of financial liberalization on the productivity growth of the Agricultural Sector?

3) Is there a permanent effect of shock and Structural breaks to financial liberalization and productivity growth of the Agriculture Sector?

\section{Literature Review}

\subsection{Endogenous Growth Theory}

Endogenous growth theory has been chosen as the theoretical approach to studying productivity growth in this study. Kaldor (1957) noted that Endogenous growth theory was brought into the scene as an important improvement upon the Neoclassical Growth and the Harrod- Domar Growth Models. Endogenous growth theory highlight explicitly the main sources of technological progress that drives sustainable productivity growth. The theory emphasize that productivity growth is a function of growth in both inputs and efficiency in the transformation process (Kaldor, 1957; Koushik, 2017). Endogenous growth theory explains how economic activities that have got to do with the creation of new technological knowledge drives long-run growth. According to this theory, long-run economic growth is made to depend on growth of total factor productivity (TFP), which is also a function of the rate of technological progress.

\subsection{Theory of Financial Liberalization}

Subsequent to the seminal work on finance-growth nexus presented by Schumpeter (1911) several other studies including the work of goldsmith (1969), McKinnon (1973) and Shaw (1973) also emerged to buttress the theory originated by Schumpeter. These studies are recognized as the foundation of the theories for analyzing the influence of financial liberalization on productivity growth in developed and also in developing economies. The studies by Schumpeter (1911) which is popularly known as the initial framework that explains the link between finance and growth hypothesis emphasizes that the presence of well-functioning financial system in an economy constitute an important first step for generating technological innovation which comes about as a result of proper allocation of economic resources in such a manner that resources flow from unproductive to productive sectors within an economy. The argument initiated by Schumpeter is confirmed by Patrick's supply-leading hypothesis which also maintained that when well-functioning financial market and the accompanying services are made available in advance of the time they are needed, they are able to drive the real sectors on the path of growth. This is achieved through efficient transfer of scarce economic resources from surplus spending units to deficit spending units in accordance with the highest rates of return on investment (Patrick, 1966).

\subsection{Approaches to Productivity Measurement}

The definition of productivity as given by Hulten (2001) is understood as the efficiency with which inputs are converted into output. In this regard productivity is recognized as a derived measure, as against the notion of straightforward concept that can be directly observed. The explanation given here has made the methods of calculating productivity diverse and several in its approach. Therefore, whichever method of calculation that is opted for has its basis on the purpose for which measurement is being performed; the unit of measurement that is applied and availability of data for the measurement (OECD, 2001). Measurement of productivity can be done 
using single factor productivity measure; example is labor productivity (OECD, 2001). This approach offers an output measurement which is usually associated with a single measure of input. An alternative approach is where productivity is measured by means of multifactor productivity measure as Total Factor Productivity (TFP). With this approach, measurement of output is associated with an observable group of input. Another issue subsequent to two measures outlined above, is the means of selecting an appropriate inputs and outputs where an output is measured by means of gross measure or value added approach (OECD, 2001).

\subsubsection{Total Factor Productivity (TFP)}

Total factor productivity (TFP) is adjudged as the measure that provides comprehensive measurement of productivity. TFP, as defined by Kathuria et al. (2011) as the ratio of output (or value added) to a weighted sum of the inputs used in the production process. Due to the nature of its inclusiveness, it is not affected by challenge of changing factor intensities in production. The measurement process of TFP considers both intermediate inputs and capital intensity. Notwithstanding the criticisms leveled against the TFP as a concept for measuring firm or industry level productivity, several authors have employed it as a measure of firm level or industry level productivity (Gatti \& Love, 2008; Grilli \& Murtinu, 2011; Colombo et al., 2011; Harris \& Li, 2012; Ackah et al., 2012; Levine \& Warusawitharana, 2014).

\subsection{The Production Function and Its Measurement}

Measurement of Production Function and the estimation of productivity at sector, industry or firm level is essentially a question of how input and output should be measured. Various authors have used different methods and approaches in the measurement of production function and productivity. Saliola and Seker (2011) and Ahiakpor and Dasmani (2012) conveniently approach the subject from gross output measures using revenue or sales as indicators. Value added approached was preferred by these authors over the gross output method (Ospina \& Schiffbauer, 2010; Levine \& Warusawitharana, 2014). Others who combined the two (both gross output and value added approaches) are Biatour et al. (2011) and Ackah et al. (2012). The approach opted for depends on data availability. For instance, the value added approach can be used only when data on intermediate inputs is available.

\subsection{Nexus between Financial Liberalization and Productivity Growth}

Financial system in both developed and developing countries perform important functions which no country in the global economy can ignore. Among these functions are mobilizations of financial resources from surplus spending units for productive activities; also important among the functions is that financial system facilitates risk management. Significant to economic growth is the ability of a country to reallocate economic resource from sectors that are considered less productive to the most productive sectors. These intermediation process are all facilitated by financial system (Levine, 1997). Schumpeter (1912) laid the theoretical foundation for the nexus between well-developed financial system and enhanced productivity growth. This argument has been confirmed and further enhanced by subsequent studies (Greenwood \& Jovanovic, 1990; King \& Levine, 1993). Sound economic policies when well implemented within an economy has a greater tendency to eliminate financial distortions. Quite apart from such policies, other studies such as Dabla-Norris et al. (2013) and Aghion et al. (2005) have discovered that capital market development exerts a closer and stronger influence on productivity growth. Evidence revealed by Dabla-Norris et al. (2013) again clearly indicate that structural reforms have been found to be one of the productivity growth enhancing economic intervention that both developed and developing economies have benefited from due to its ability to allocate resources needed to boost productive capacity. Ample evidence abound in other related study in literature that support the view that trade openness, efficient and well-developed financial systems, and national institutions endowed with the capacity to promote competition and facilitate entry and exit, facilitate productivity growth at the cross-country, sector, industry and firm levels (Christiansen et al., 2013; OECD, 2013; Prati et al., 2013; Restuccia \& Rogerson, 2013; Bourles et al., 2013).

\subsection{Emperical Literature}

Empirical literature on the influence of financial liberalization on productivity growth reveals diverse kinds of results. The reasons that have accounted for these different results have been documented in literature. Some of these reasons are: estimation methodology (Krishnan et al., 2014, Nandy \& Puri, 2014), stage of development of the economy (Chauvet \& Jacolin, 2015; Gatti \& Love, 2008), data used whether primary of secondary and sample size employed (Ali \& Najman, 2015).

Even though, no single reform path can be identified, historical experience has made it clear that real and financial sector reforms have the capacity to drive productivity growth and it is on this basis that the benefits of productivity resulting from change in the component of output toward high-productivity sectors continue to played essential role in both emerging market and developing economies (Dabla-Norris et al., 2013). They also 
emphasized that productivity growth in economic sectors such as industry and agriculture in emerging market economies have performed better than the services sector during the reforms period. However, they also noted that in the low income countries productivity growth in the agriculture and service sectors exceeded that of the manufacturing sector. Given this background, the argument in favor of the growth and development of agricultural sector as a critical factor for socioeconomic development in developing economies could be supported. Governments and institutions in the sub-Saharan African (SSA) sought for strategies that could be implemented to ensure higher levels of production and as an important means of sustainable growth in agricultural production improvement of productivity through technological and efficiency changes (Ajao, 2011).

Several other empirically studies carried out on the relationship between financial liberalization and productivity growth have confirmed the assertion that there is a strong link between financial liberalization and productivity growth as reported by several researchers on the subject. Beck et al. (2000) examined the nexus between financial intermediary development and sources of growth. Economic variables such as private credit and liquid liabilities were used as proxies for measuring financial intermediary development in 63 economies for the period spaning 1960-1995; The authors' report indicate that there is a strong positive link between financial intermediary development and real per capita GDP growth as well as total factor productivity growth. Other empirical studies have also shed light on the fact that efficient financial systems enhance investment and innovation (Levine, 2005). The implication is that in countries where efficient financial systems have been secured, there is a higher propensity that they could take advantage of technology transfer. Efficiency in capital allocation across and between firms and industries have always been driven by well-developed financial systems (Rajan \& Zingales, 2001; Tressel, 2008). Larrain and Stumpner (2013) found that in 10 Eastern European countries that pursued reforms directed at bringing a decline in financial repression, it was found that manufacturing productivity grew by $17 \%$ as a result of proper allocation of resources across and within firms and industries.

Chipeta (2012) also discovered that Cross-country analysis have generated evidence to support the assertion that productivity payoffs of financial liberalization vary across countries at different stages of development. That notwithstanding, access to credit and their influence on productivity growth may not differ across countries at different levels of development. He cited specific industrialized countries such as Bulgaria, China and other developing countries in Africa such as Tanzanian.

Empirical evidence discovered by Krishnan, Nandy, and Puri (2014) is relevant in this discussion. According to Nandy and Puri (2014), in any economy where smaller and financially constrained firms are resourced with bank financing, the effects on productivity have always been positive. Others (Krishnan et al., 2014; Chauvert \& Jacolin, 2015), whose studies were based on natural experiment of US private and public manufacturing firms, following the interstate banking deregulation which opened bank financing to firms yielded positive result. Their findings did not differ from that of Robb and Robinson (2014) who also reported that access to bank finance is a critical factor in firms' productivity, especially when small and startup firms are involved. Another evidence of interest was found by Ali and Najman (2015). They noted that line of credit and savings have proved to have a strong positive link with productivity growth measured by Total factor Productivity (TFP).

In African, as it does happen in other developing countries, empirical studies have not yielded opposing results. In a study where a large survey of 33 African and other developing countries were tested, Ali and Najman (2015) observed that where the firms in those countries had difficulty in accessing finance, such financial bottlenecks impact negatively on their productive performance. However, if the same firms are given free access to external finance, their productivity improves. International Finance Corporation (IFC) (2013) also lend credence to this assertion and stated that financial constrain constitute a major obstacle to enterprise growth and productivity among small and medium sized firms. Osei-Assibey (2013) did not arrive at a contrary result in Ghana, when he found that medium and small enterprise when open to increased access to debt finance or loan maintains higher productivity levels.

In order to discover what determines both firm and country level determinants of productivity growth, Chauvet and Jacolin (2015) distinguished between firm level and country level data in their assessment of the factors that influence firm level and country level determinants of productivity. They concluded that statistically, foreign ownership, size of a firm , export and overdraft facility are the major determinants of firm-level productivity, however, with regard to country level productivity determinants, they reported that Growth in GDP, income per capita, size of population and the state of corruption in a given country significantly influence country level productivity growth.

Cole et al. (2016) conducted a study in which they modeled firm technology adoption decisions for India, Mexico and the United States in which external financing served as a critical determinant. It was discovered that a key 
driver for a firm to adopt an advanced technologies for the purpose of promoting higher productivity could be realized from financial system that engages in long-term contracts and efficient performance monitoring. They found that advanced production technologies much depends on huge initial capital investment whereas the payoff comes late in the firm's development cycle. For this same reason developed countries such as US which have in place efficient financing institutions and mechanisms conveniently and economically take advantage of adopting such advanced technologies. India and Mexico run flexible systems that allow the adoption of entry-level and intermediate-level technologies, therefore their financing needs are lower with shorter pay-off horizons when compared to advanced technology. The implication is that differences in TFP between countries can be explained by the kind of technology choice they make. An important insight from the study by Cole et al. (2016) is that India and Mexico have the potential to raise their TFP by $46 \%$ and $43 \%$ respectively on the condition that their financial system were comparable with that of United States (Cole et al., 2016; Ali \& Najman, 2015).

Adusei (2013) applied annual time series data from 1971 to 2010 for a related study in Ghana. Contrary to the previous study, he used The Fully Modified Ordinary Least Square (FM-OLS), Error Correction Model (ECM) and Generalized Method of Moments (GMM) as the estimations strategies. He noted that finance obstruct economic growth in Ghana. His findings revealed that financial liberalization undermines growth and therefore not beneficial to the economy. The study also reported that money supply to GDP ratio and domestic credit to GDP ratio do not favour growth in both the long-and short-run (Adusei, 2013).

\section{Methodology}

\subsection{Research Design}

The research design adopted for this study is descriptive, quantitative research design. The aim of the study was to conduct a systematic examination of the series variables used in the study so as to establish and measure the relationship that exist between financial liberalization and agricultural productivity growth, using sector-level data. The study employed multivariate analysis model.

\subsection{Statistical Data Analysis/Procedures}

The study adopted econometric approach in the analysis of data. Therefore, econometric models such as Error correction model which examined the short run and long run association among the variables as well as the multivariate regression analysis were applied

\subsection{Econometric Estimation Techniques}

The investigation and examination of the stationarity properties of the series variables and long run relationship was based on testing for unit root and performance of cointegration test using the Gregory and Hansen cointegration approach.

\subsection{Nature and Sources of Data}

The data used in the econometric analysis in this study was purely secondary data. Annual time series data from 1970 to 2013 was used. Data was sourced from issues of World Bank's, World Development Indicators, IMF's International Financial Statistics, Bank of Ghana, as well as Ghana Statistical Services Reports.

\subsection{Measurement of Productivity}

The following production functions were considered in the estimation of the Total Factor Productivity (TFP): Transcendental Logarithmic (Translog) Production Function, Constant Elasticity of Substitution (CES) and CobbDouglas production function among others. Considering the previous works of the following authors (Chen \& Guariglia, 2011; Osei-Assibey, 2013; Gatti \& Love, 2008; Arnold et al., 2008), this study made use of the Cobb-Douglas Production Function for the Estimation of the Total Factor Productivity (TFP).

\subsubsection{Estimating Total Factor Productivity (TFP)}

The Value-Added-Based Total Factor Productivity measure was employed.

The standard Cobb-Douglas production function is given in equation (1):

$$
Y_{i t}=T F P_{i t} L_{i t}^{\beta_{L}} K_{i t}^{\beta_{k}} \sum_{m=1}^{M} X_{i m t}^{\beta}
$$

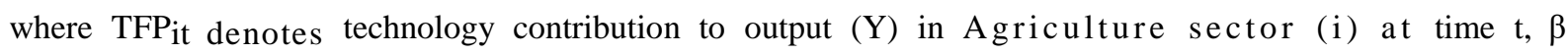
coefficients represents each factor's $(\mathrm{X})$ estimated output elasticity and $\mathrm{m}=(1,2 \ldots \mathrm{m})$

Equation (1) is then transformed into a log-log model as in equation (2)

$$
\ln Y_{i t}=\ln T F P_{i t}+\beta_{L} \ln L_{i t}+\beta_{k} \ln K_{i t}+\beta_{1} \ln X_{i 2 t}+\beta_{2} \ln X_{i 2 t}+\ldots . .+\beta_{m} \ln X_{i m t}
$$

The productivity level is determined as the residual of the $\left(\operatorname{lnTFP}_{\mathrm{it}}\right)$ by deducting from output the observable inputs 
contributions weighted by their corresponding output elasticities.

$$
\ln T F P_{i t}=\ln Y_{i t}-\beta_{L} \ln L_{i t}-\beta_{k} \ln K_{i t}-\beta_{1} \ln X_{i 2 t}-\beta_{2} \ln X_{i 2 t}-\ldots . .-\beta_{m} \ln X_{i m t}
$$

Using the value added approach, where value added (VA) is defined as the difference between the value of gross output and the value generated by intermediate inputs $\left(\mathrm{X}_{1} \ldots \mathrm{X}_{\mathrm{M}}\right)$ :

$$
\ln V A_{s t}=\ln Y_{s t}-\beta_{1} \ln X_{1}+\beta_{2} \ln X_{2}+\ldots . .+\beta_{m} \ln X_{m}
$$

The log productivity measure for the Sector's -year observation, $\mathrm{TFP}_{\mathrm{st}}$ is taken as the residual from analogous $\log -\log$ model given in equation (3):

$$
\ln T F P_{s t}=\ln V A_{s t}-\beta_{L} \ln L_{s t}-\beta_{k} \ln K_{s t}
$$

In this sense, TFP growth $\left(\operatorname{lnTFP}_{\mathrm{it}}-\operatorname{lnTFP}_{\mathrm{it}-1}\right)$ is explained as the value added not caused by an increase in factor input (labor and capital)

The regression estimation given below is therefore based on equation (4)

$$
\ln Y_{s t}=c+\alpha \ln K_{s t}+\beta \ln L_{s t}+\varepsilon_{s t} .
$$

With $\mathrm{Y}_{\mathrm{st}}$ representing value-added by sector (s) in year $(\mathrm{t})$, and $\mathrm{K}_{\mathrm{st}}$ and $\mathrm{L}_{\mathrm{st}}$ denoting capital and labor inputs respectively. The log specification given in equation (6) assumes a Cobb-Douglas model for value-added by Agriculture sector. The aim is not to impose a constant returns-to-scale restriction in the above model, however, both the capital and labor elasticities will be estimated.

The log productivity measure for the Sector-year observation, $\mathrm{TFP}_{\mathrm{st}}$ is considered as the residual from equation (3). The Log growth rate of Productivity which was used as the dependent variable for the subsequent models is determined by taking differences of this residual. This is expressed as:

$$
T F P_{s t+1}=T F P_{s t-1}-T F P_{s t} .
$$

In the model, capital is measured using the replacement value of capital while labor measured as the staff cost of employees. The replacement value of capital is computed based on double reducing balance approach (Summers \& Salinger, 1983). This approach permits the application of potential differences in the quality of the capital stock. Using staff cost of labor in the measurement of labor input also allows the possibility of capturing the potential differences in the employee's skill level. The TFP measure that is estimated indicates the amount of value-added of the sector over and above what can be assumed to be coming from its capital and labor inputs. To this end it can be concluded that, any addition to TFP indicates that where input factors are held constant, the sector generates substantial amount of value-added to productivity.

\subsection{Model Specification}

The next important consideration following the Total Factor Productivity (TFP) estimation is to regress on its policy variables. The policy variables used in this study are financial liberalization proxied by Credit to Private-Sector (BSLIB), Sector-Level Investment (SLINV) Capital Account Openness (CAOPN) and Trade openness (TLIB). There are other potential determinants of sector level productivity growth identified in literature such as, Market Capitalization and Credit Control Relaxation). However, empirical theory does not emphasized on any particular determinant which is required in an empirical model. The study therefore follows the stepwise approach in which as many significant variables as the data may provide is permissible in the model.

The baseline model for this study is based on the endogenous growth model. Following other prior studies such as Adusei (2013) and also on the account of the theoretical literature, the model for the study is specified as:

$$
T F P_{s t+1}=\alpha_{1} T F P_{s t}+\alpha_{2} T F P_{s t-1}+\gamma F i n l i b_{t}+\beta X_{s t}+v_{s}+\varepsilon_{s t+1} \text {. }
$$

With $\mathrm{TFP}_{\text {it }+1}$ denoting real productivity growth from year $\mathrm{t}$ to $\mathrm{t}+1$; Finlib $\mathrm{b}_{\mathrm{st}}$ denotes financial liberalization index, $\mathrm{X}_{\mathrm{st}}$ represents a set of additional controls; and $v_{\mathrm{s}}$ denotes a sector fixed effect. The coefficient of interest, $\gamma$, is given as the elasticity term. The lagged productivity growth terms are included for the purpose of accounting for the mean reversion in productivity observed in the data. $\varepsilon$ denotes the idiosyncratic error term. An observed positive coefficient for $\gamma$ indicates that financial liberalization has expansionary effect on the productivity growth on Agriculture sector.

The control variables recognized in this study comprise sector's size, government expenditure, market capitalization and credit control relaxation. Considering the significance of these control variables, a positive relationship with productivity is expected. Government expenditure given as a percentage of GDP included as one of the control variables is the recognition of the significant contribution of the government involvement in economic growth. This influence is expected to be positive; however, it might also be negative due to the crowding out effect as caused by private investment (Adusei, 2013). A sector's size variable is also added as a control 
variable to soak up the sector-specific characteristics in an economic system (Maskus et al., 2012; and Friedrich et al., 2012).

\subsection{Estimation Strategy}

In order to ensure consistency in the time series regression analysis, regarding the data and parameter estimates, the study followed three important steps for the estimation of the parameters involved in the estimable model. In the first place, the stationarity properties of the variables were examined. The next step followed was testing for the presence or otherwise of cointegration (long-run relationship) amongst the variables. Finally, the long-and short-run parameters were estimated.

\subsubsection{Unit Root Test without Structural Break}

Unit root test was used to investigate the stationarity properties of the variables. This test is relevant because time series variables that are non-stationary yields spurious estimations results. Again testing for the stationarity properties is necessary in order to determine the order of integration for the purpose of choosing appropriate econometric technique. Series that are non-stationery should be made stationery through differencing. Augmented Dickey-Fuller (1981) (ADF) and the Kwiatkowski et al. (1992, KPSS) were the two main unit root tests used for the unit root test not involving structural break.

Nanthakumar and Subramaniam (2010) specified, the ADF test as:

$$
\Delta Y_{t}=\alpha_{t}+\beta_{t} \gamma_{t}+\rho Y_{t-1}+\sum_{i=1}^{q} \partial \Delta Y_{t-1}+\varepsilon_{t}
$$

In this equation $\gamma$ is time trend, $\mathrm{Y}$ denotes time series variable in the model, $\varepsilon_{\mathrm{t}}$ is the error term or stochastic error term. $\mathrm{Y}_{\mathrm{t}}$ is the level of the series variable, $\mu$ denotes the drift term, $\mathrm{T}$ represents the time trend, $\mathrm{P}$ is the number of lags, $\Delta$ shows that the series are in their first difference. The $\varepsilon_{\mathrm{t}}$ is the error term/ white noise with features of normal distribution. The error term $\left(\varepsilon_{t}\right)$ has an expected mean value of zero $(0)$ and a constant variance. The critical values are compared with the computed values at $5 \%, 1 \%$ and $10 \%$ levels of significant.

\subsubsection{The KPSS Test}

The main purpose of the KPSS test is to confirm the ADF test results. The null assumption for the KPSS test is that the series variables are stationary while the alternative assumption states that the series are non-stationary (Kwiatkowski et al., 1992).

The KPSS Test is given in an equation form as in equation (10)

$$
X_{t}=\xi t+r_{t}+\varepsilon_{t}
$$

Given that $X_{t}$ is the series variable under examination; $t$ denotes the deterministic trend, $r_{t}$ is the random walk, while the stationary error is given by $\varepsilon_{t}$.

It is also possible to express the random walk in an equation form as:

$$
r_{t}=r_{t-1}+\mu_{t} \text {. }
$$

Where $\mu_{\mathrm{t}}$ is equal to IID $\left(0, \sigma_{\mu}^{2}\right)$. $\mathrm{r}_{\mathrm{t}}$ has an initial value of zero (0) given by $\mathrm{r}_{0}$ and also fixed. It represents the intercept in the model.

The test statistics for KPSS method is the Lagrange multiplier (LM) statistic with the assumption that $\sigma_{\mu}^{2}=0, \mu_{\mathrm{t}}$ is normally distributed while the error term $\left(\varepsilon_{t}\right)$ is IID $N\left(0, \sigma_{\varepsilon}^{2}\right)$.

With regard to this a partial sum process of the residuals can be expressed as:

$$
S_{t}=\sum_{i=1}^{t} e_{i}
$$

Where $\mathrm{t}=1,2,3 \ldots \mathrm{T}$.

The LM statistic is expressed in equation (13):

$$
L M=\sum_{t=1}^{T} S_{t}^{2} / \hat{\sigma_{\varepsilon}^{2}}
$$

\subsection{Unit Root Test with Structural Breaks}

In analyzing time series variables that involve structural breaks, various tests such as Zivot-Andrews (1992) and Clemente, Montanes, and Reyes (1998) tests were used in the study. The Zivot-Andrews (ZA) unit root test was employed in the examination and investigation of unit root with one endogenously determined structural break. The break dates are estimated but they are not considered as fixed. In the investigation using the ZA test, only a 
single break is allowed in the intercept and the trend of the series variable under investigation.

The following equations give the expression of the ZA tests.

$$
\begin{gathered}
y_{t}=\alpha_{0}+\alpha_{1} D U_{t}+d(D T B)_{t}+\beta_{t}+p y_{t-1}+\sum_{i=1}^{p} \emptyset_{i} \Delta y_{t-1}+e_{t} \\
y_{t}=\alpha_{0}+\gamma D T_{t}^{*}+\beta_{t}+p y_{t-1}+\sum_{i=1}^{p} \emptyset_{i} \Delta y_{t-1}+e_{t} \\
y_{t}=\alpha_{0}+\alpha_{1} D U_{t}+d(D T B)_{t}+\gamma D T_{t}+\beta_{t}+p y_{t-1}+\sum_{i=1}^{p} \emptyset_{i} \Delta y_{t-1}+e_{t}
\end{gathered}
$$

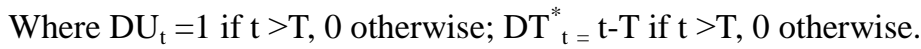

The null Hypothesis in the case of equation (15b) states that the time series variable under investigation is integrated without an exogenous structural break. The alternative hypothesis on the other hand assumes that the series is trend-stationary with a break point occurring in the trend at an unknown point. Given these, the break point can be estimated at a point that favours the alternative hypothesis.

$$
y_{t}=\beta+y_{t-1}+e_{t},
$$

The information criteria used in selecting the lag length include: Schwartz Information Criterion (SIC) Hannan-Quinn Information Criterion (HQI), Akaike Information Criterion (AIC) and Bayesian Information Criterion (BIC). The t-test was also useful as an additional selection processes.

It may happen that the series variables may exhibit multiple breaks, in the event of such occurrences, the ZA test might not be appropriate in dealing with it. Series variables that exhibit multiple breaks, requires an appropriate test as one developed by Clemente, Montanes, and Reyes (1998) which is the appropriate test that permits multiple structural breaks to be investigated.

The assumptions, both the Null and the alternative assumptions underlying the test are expressed in the equations (17) and (18).

$$
\begin{array}{r}
H_{0} ; x_{t}=x_{t-1}+\delta_{1} D T B_{1 t}+\delta_{2} D T B_{2 t}+\mu_{t}, \\
H_{1} ; x_{t}=\mu+\theta_{1} D U_{1 t}+\theta_{2} D T B_{2 t}+\varepsilon_{t},
\end{array}
$$

Where DTBit is the dummy variable. $\mathrm{DTB}_{\mathrm{it}}=1$ if $\mathrm{t}=\mathrm{TB}_{\mathrm{i}}+1,0$ otherwise. $\mathrm{DU}_{\mathrm{it}}=1$ if $\mathrm{t}>\mathrm{TB}_{\mathrm{i}}$ (for $\mathrm{i}=1,2$ ), 0 otherwise. TB1 and TB2 indicate the period for the break point. Clemente et al. (1998) specified that TBi $=\lambda \mathrm{iT}$ (for $\mathrm{i}=1,2$ ) for the range $0<\lambda_{i}<1$ and $\lambda_{2}>\lambda_{1}$.

The estimation of the break points is dependent on innovative and additive outliers.

Equation (19) specify the model for the innovative outlier

$$
x_{t}=\mu+\rho x_{t-1}+\delta_{1} D T B_{1 t}+\delta_{2} D T B_{2 t}+\theta_{1} D U_{1 t}+\theta_{2} D U_{2 t}+\sum_{i=1}^{k} c_{j} \Delta x_{t-i}+\varepsilon_{t},
$$

The assumption underlying the asymptotic distribution of the test statistic model (190 is given in model (20).

$$
0 \prec \lambda_{0} \prec \lambda_{1}, \lambda_{2} \prec 1-\lambda_{0} \prec 1 \text {. }
$$

Given that $\lambda_{1}$ and $\lambda_{2}$ take the values of $[(t+2) / T,(T-1 / T)]$

Given the assumption that $\lambda_{2}>\lambda_{1}+1$, the situation the breaks occur at conservative period can be eliminated.

Examination of structural break involving additive outliers performed by employing the models specified in equations (21) and (22).

$$
x_{t}=\mu+\theta_{1} D U_{1 t}+\theta_{2} D U_{2 t}+\tilde{x}_{\text {.. }}
$$

Equation (22) is estimated the assumption that $\rho=1$. The minimum value of t-ratio is applied in testing for the null assumption that $\rho=1$.

$$
\tilde{x}_{t}=\sum_{i=0}^{k} \omega_{1 i} D T B_{1 t-i}+\sum_{i=0}^{k} \omega_{2 i} D T B_{2 t-i}+\rho \tilde{x}_{t-1}+\sum_{i=1}^{k} c_{i} \Delta \tilde{x}_{t-i}+\ell_{t} \cdot
$$

In this regard DTBit is the dummy variable included in the model to ensure that min $\mathrm{t}^{\mathrm{A} 0}{ }_{\mathrm{p}^{\wedge}}\left(\lambda_{1}, \lambda_{2}\right)$ converges to the distribution.

$$
\min t_{\rho}{ }^{A 0}\left(\lambda_{1}, \lambda_{2}\right) \rightarrow \inf \lambda=\wedge \frac{H}{\left[\lambda_{1}\left(\lambda_{2}-\lambda_{1}\right)\left(1-\lambda_{2}\right)\right]^{0.5} k^{0.5}} \cdots
$$

\subsection{Cointegration Analysis using Gregory and Hansen Methodology with Structural Breaks}

The Gregory and Hansen Methodology of cointegration performs better than Johanson approach in the investigation of long run and short run relationship involving endogenous structural breaks. There are four main 
models in the process as specified in equations $(24,25,26$ and 27) which are specifically developed for this purpose. The two variables defined in the equations: $\mathrm{M}$ and $\mathrm{N}$ are such that $\mathrm{M}$ represents the dependent variable and $\mathrm{N}$ denoting the independent variable. $\mathrm{e}$ is the error term $\mathrm{t}$ is time subscript; while $\mathrm{k}$ is the break date.

$$
M_{t}=\theta_{1}+\theta_{2} f_{t k}+a_{1} N_{t}+e_{t},
$$

Model A: Level Shift

$$
M_{t}=\theta_{1}+\theta_{2} f_{t k}+\delta_{1} t+a_{1} N_{t}+e_{t},
$$

Model B: Level Shift with Trend

Model C: Regime Shift with change in Intercept and Slope coefficients

$$
M_{t}=\theta_{1}+\theta_{2} f_{t k}+\delta_{1} t+a_{1} N_{t}+a_{2} N_{t} f_{t k}+e_{t},
$$

Model D: Regime Shift with change Intercept, Slope coefficients and Trend

$$
M_{t}=\theta_{1}+\theta_{2} f_{t k}+\delta_{1} t+\delta_{2} t f_{t k}+a_{1} N_{t}+a_{2} N_{t} f_{t k}+e_{t},
$$

An additional equation is required when estimating the dummy variables in equations (24) to (27). This is equation (28) specified below.

$$
\mathrm{f}_{\mathrm{tk}}=0 \text { if } \mathrm{t} \leq \mathrm{k} \text { and } \mathrm{f}_{\mathrm{tk}}=1 \text { if } \mathrm{t}>\mathrm{k}
$$

Determining the break date is made dependent on the estimation of the cointegration equations for all possible break dates in the series being examined. The minimum t-statistics is the basis for selecting the break date or ADF test statistic is maximum in absolute term. Critical values in Engle-Granger model by Gregory and Hansen (1996) is employed in investigating cointegration in the presences of unknown structural breaks.

\section{Results and Discussion}

\subsection{The Unit Root Tests without Structural Breaks}

There are three main basic approaches for determining stationarity properties of series variables as to whether there is unit root or not. These approaches are: differencing stationary process (DSP), trend stationary process (TSP), and log transformation process. The first which involves differencing stationary process (DSP was used as a test for stationarity.

\subsubsection{The ADF Test without Structural Breaks}

The results on the ADF test for unit root are reported in Table 1. The results of the ADF test for unit root in levels show that all the series variables are non-stationary in intercept. The null hypothesis of unit root was accepted for all these series.

Table 1. The ADF test without structural breaks

\begin{tabular}{lllll}
\hline variable(Level) & t-statistics & ADF/P-Value & Results & Lag length \\
\hline TLIB & -1.149 & 0.698 & Not stationary & 1 \\
BSLIB & -0.522 & 0.885 & Not stationary & 1 \\
CAOPN & -1.696 & 0.098 & Not stationary & 1 \\
SLINV & -3.149 & 0.003 & Not stationary & 1 \\
ASP & -1.784 & 0.389 & Not stationary & 1 \\
\hline
\end{tabular}

Source: Author's computation.

Taking the first difference of the series in linear form and testing these with intercept, and trend makes the series stationary. That is, the null hypothesis of unit root is rejected. The results are reported in Table 2 These results indicate that most of the series exhibit unit root processes in levels.

Table 2. The ADF test without structural breaks

\begin{tabular}{lllll}
\hline Variable (1st dif.) & t-statistics & ADF/P-Value & Results & Lag length \\
\hline TLIB-1st dif. & -5.398 & $2.92 \mathrm{e}-06 * * *$ & Stationary & 1 \\
BSLIB-1st dif. & -5.591 & $1.08 \mathrm{e}-06 * * *$ & Stationary & 1 \\
CAOPN-1st dif. & -3.557 & $0.001 * * *$ & Stationary & 1 \\
SLINV-1st dif. & -6.378 & $0.000 * * *$ & Stationary & 1 \\
ASP-1st dif. & -7.099 & $1.78 \mathrm{e}-010 * * *$ & Stationary & 1 \\
\hline
\end{tabular}

Source: Author's computation.

\subsection{The KPSS Test without Structural Breaks}

The KPSS test is based on the null assumption (Ho) that the series variables under investigation are stationary 
against the alternative hypothesis (H1) that the series are not stationary The KPSS is a reversed test for unit root. It is used in this study for confirmation of the stationarity properties of the series. The results are reported in Table 3, and Table 4.

The series were examined in levels in linear form (Table 3 ) and in first difference (Table 4). The results in Table 4 indicate mixed results. Some series are unit root in levels but become stationary in first difference, indicating that they are integrated of order one, I (1). Series variables that are stationary at levels are integrated of other zero, I (0). The levels of significance are $1 \% ; 5 \%$ and $10 \%$. Some series are stationary at $10 \%$ but not at $1 \%$ and $5 \%$. The results indicate the series are stationary in first difference.

Table 3. The KPSS test without structural breaks

\begin{tabular}{lllll}
\hline Variable(Level) & t-statistics & P-Value & Results & Lag length \\
\hline TLIB & 0.132 & 0.082 & stationary & 3 \\
BSLIB & 0.252 & n.a & Not stationary & 3 \\
SLINV & 0.140 & n.a & Not stationary & 3 \\
CAOPN & 0.174 & n.a & Not stationary & 3 \\
ASP & 0.055 & n.a & stationary & 3 \\
\hline
\end{tabular}

Source: Author's computation. Critical values at $10 \%, 5 \%$ and $1 \%$ significant levels are $0.119 ; 0.146 ; 0.216$ respectively.

Table 4. The KPSS test without structural breaks

\begin{tabular}{lllll}
\hline Variable (First diff.) & t-statistics & P-Value & Results & Lag length \\
\hline TLIB-1st dif. & 0.120 & n.a & Stationary & 3 \\
BSLIB-1st dif. & 0.092 & n.a & Stationary & 3 \\
SLINV-1st dif. & 0.099 & n.a & Stationary & 3 \\
CAOPN-1st dif. & 0.144 & n.a & Stationary & 3 \\
ASP-1st dif. & 0.041 & n.a & Stationary & 3 \\
\hline
\end{tabular}

Source: Author's computation. Critical values at $10 \%, 5 \%$ and $1 \%$ significant levels are $0.119 ; 0.146 ; 0.216$ respectively.

\subsection{Testing Unit Root Allowing for Endogenous Structural Breaks}

The study used Zivot-Andrews test to examine the unit root allowing for endogenously determined structural break. The results are presented in Table 5. The Zivot-Andrews test was based on the null hypothesis of unit root with the alternative hypothesis as no unit root. With the exception of ASP, the null hypothesis of unit root could not be rejected for all the variables. The variables tested are therefore unit root with structural breaks.

Table 5. Zivot-Andrews unit root tests with structural break

\begin{tabular}{llll}
\hline Series (Level) & t-statistic & Optimal Breakpoints & Decisions \\
\hline ASP & -6.417 & 1978 & Stationary \\
BSLIB & -3.132 & 1981 & Unit root \\
TLIB & -2.560 & 2002 & Unit root \\
CAOPN & -2.659 & 1979 & Unit root \\
SLINV & -2.128 & 1979 & Unit root \\
\hline
\end{tabular}

Source: Author's computation. Critical values are 1\% (-4.93); 5\% (--4.42) and 10\% (--4.11).

Note. $* * *, * *$ and $*$ denotes statistical significance at the $10 \%, 5 \%$ and $1 \%$ levels respectively.

Table 6. Zivot-Andrews unit root tests with structural break

\begin{tabular}{llll}
\hline Series (First Diff) & t-statistic & Optimal Breakpoints & Decisions \\
\hline$\Delta$ ASP & -7.081 & 1984 & Stationary \\
$\Delta$ BSLIB & -8.747 & 1999 & Stationary \\
$\Delta$ TLIB & -3.461 & 1987 & Unit root \\
$\Delta$ CAOPN & -6.610 & 1990 & Stationary \\
$\Delta$ SLINV & -7.100 & 1996 & Stationary \\
\hline
\end{tabular}

Source: Author's computation. Critical values are 1\% (-4.93); 5\% (--4.42) and 10\% (--4.11).

Note. $* * *, * *$ and $*$ denotes statistical significance at the $10 \%, 5 \%$ and $1 \%$ levels respectively. 


\subsection{Testing for Unit Root Allowing for Two Structural Breaks}

In order to test for Unit Root Allowing for Two Structural Breaks, the Clemente-Montanes-Reyes test (1998) test was used. There are two models involved in Clemente-Montanes-Reyes test, these are the innovational outlier (IO) and Additive Outlier (AO). Table 7 gives the results for the IO model while the result for AO model are reported in Table 7. With regard to the IO model, structural changes occur gradually and allows for a break in both the slope and the intercept of the model. In the case of AO model, it is assumed that structural changes is rapid and the break is allowed only in the slope. The test was on the basis of the null hypothesis that the series are not stationary with structural breaks while the alternative hypothesis stated that the series are stationary with break. Even though structural break was reported in the series using the innovative outlier, the null hypothesis of a unit root in the series variables in levels is confirmed as shown in Table 8.

Table 7. Clemente et al. (1998) structural break with double mean shifts

\begin{tabular}{lllll}
\hline \multicolumn{4}{l}{ IO mode: IO model, structural changes take place gradually and allows for a break in both the slope and the intercept of the model } \\
Series (Levels) & t-statistics & $5 \%$ Critical Value & Optimal break Points & Decisions \\
\hline TLIB & -3.238 & -5.490 & $1984 \& 1994$ & Unit root \\
BSLIB & -3.800 & -5.490 & $1995 \& 2006$ & Unit root \\
CAOPN & -3.401 & -5.490 & $1977 \& 1992$ & Unit root \\
SLINV & -4.646 & -5.490 & $1987 \& 1991$ & Unit root \\
ASP & -0.407 & -5.490 & $1982 \& 2004$ & Unit root \\
\hline
\end{tabular}

Source: Author's computation.

The test results in first difference is as reported in Table 8. Here, the null hypothesis of unit root in the series variables is rejected.

Table 8. Clemente et al. (1998) structural break with double mean shifts

\begin{tabular}{lllll}
\hline \multicolumn{2}{l}{ IO model: In the AO model the assumption is that structural changes is rapid and allow for a break in only the slope. } \\
Series (Levels) & t-statistics & $5 \%$ Critical Value & Optimal break Points & Decisions \\
\hline$\Delta$ TLIB & -6.222 & -5.490 & $1981 \& 1999$ & Stationary \\
$\Delta$ BSLIB & -7.988 & -5.490 & $1982 \& 1998$ & Stationary \\
$\Delta$ CAOPN & -9.607 & -5.490 & $1977 \& 1993$ & Stationary \\
$\Delta$ SLINV & -7.210 & -5.490 & $1982 \& 1992$ & Stationary \\
$\Delta$ ASP & -14.618 & -5.490 & Stationary & \\
\hline
\end{tabular}

Source: Author's computation.

In the case of the additive outliers, examining structural break in the series variables in levels, the study could not reject the null hypothesis of a unit root in the series as presented in Table 9. The results as reported in Table 10 show mixed results. In level, some series are unit root but become stationary in first difference (BSL, INV and ASP).

Table 9. Clemente et al. (1998) structural break with double mean shifts

\begin{tabular}{lllll}
\hline \multicolumn{4}{l}{ AO model: In the AO model the assumption is that structural changes is rapid and allow for a break in only the slope. } \\
\hline Series (Levels) & t-statistics & $5 \%$ Critical Value & Optimal break Points & Decisions \\
\hline TLIB & -1.317 & -5.490 & $1988 \& 1998$ & Unit root \\
BSLIB & -0.236 & -5.490 & $1974 \& 1996$ & Unit root \\
CAOPN & -2.057 & -5.490 & $1977 \& 1995$ & Unit root \\
SLINV & -4.718 & -5.490 & $1975 \& 1990$ & Unit root \\
ASP & -1.162 & -5.490 & $1980 \& 2003$ & Unit root \\
\hline
\end{tabular}

Source: Author's computation.

Table 10. Clemente et al. (1998) structural break with double mean shifts

\begin{tabular}{lllll}
\hline \multicolumn{4}{l}{ AO model: In the AO model the assumption is that structural changes is rapid and allow for a break in only the slope. } \\
\hline Series (Levels) & t-statistics & $5 \%$ Critical Value & Optimal break Points & Decisions \\
\hline$\Delta$ TLIB & -1.973 & -5.490 & $1982 \& 2004$ & Unit root \\
$\Delta$ BSLIB & -6.940 & -5.490 & $1981 \& 1997$ & Stationary \\
$\Delta$ CAOPN & -5.478 & -5.490 & $1976 \& 1992$ & Unit root \\
$\Delta$ SLINV & -7.513 & -5.490 & $1981 \& 1991$ & Stationary \\
$\Delta$ ASP & -6.418 & -5.490 & $1981 \& 1984$ & Stationary \\
\hline
\end{tabular}

Source: Author's computation. 


\subsection{Gregory and Hansen Estimates of Productivity Growth of Agriculture Sector}

In this section, Agriculture sector productivity growth is modeled using Gregory-Hansen (G-H) Co-integration approach in the presence of structural breaks. Gregory-Hansen test is used in the current study due to the fact that in dealing with structural breaks, it performs better than Johansen approach and the ARDL model in the presence of structural breaks.

The results (Table 11) on the estimated models provides enough evidence of cointegration given the various assumptions (a level shift; a level shift with a trend; a regime shift which also allows the slope vector to shift and a regime shift which allows the slope vector to shift with a trend) employing the ADF/Zt values. In the model, four main explanatory variables are estimated for the long run parameters.

Table 11. Gregory-Hansen structural break cointegration test (Agricultural Sector Value Added Model)-Model C; Model C/T; Model C/S and Model C/S/T)

\begin{tabular}{|c|c|c|c|c|c|c|c|}
\hline Variables & Model & $\mathrm{ADF}$ & $\mathrm{BP}$ & $\mathrm{Zt}$ & $\mathrm{BP}$ & $\mathrm{Z} \alpha$ & $\mathrm{BP}$ \\
\hline ASP, $\quad$ TLIB & $\mathrm{C}$ & -8.530 & 1981 & -8.630 & 1981 & -56.070 & 1981 \\
\hline \multirow[t]{3}{*}{ SLINV,CAOPN } & $\mathrm{C} / \mathrm{T}$ & -8.330 & 1981 & -8.420 & 1981 & -55.000 & 1981 \\
\hline & $\mathrm{C} / \mathrm{S}$ & -3.740 & 1979 & -8.990 & 1981 & -57.610 & 1981 \\
\hline & $\mathrm{C} / \mathrm{T} / \mathrm{S}$ & -8.780 & 1981 & -8.880 & 1981 & -57.030 & 1981 \\
\hline
\end{tabular}

Source: Author's computation.

\subsection{Growth in Multivariate Model Using Gregory-Hansen Method}

In this section of the study, determinants of Agriculture sector productivity growth are modeled using Gregory-Hansen (G-H) Co-integration approach in the presence of structural breaks. The results on the estimated models [model $\mathrm{C}$; model $\mathrm{C} / \mathrm{T}$; model $\mathrm{C} / \mathrm{S}$ and model $\mathrm{C} / \mathrm{S} / \mathrm{T}$ ] are reported in Table 12. The results revealed evidence of no significant cointegration in models $\mathrm{C}$, model $\mathrm{C} / \mathrm{S}$ and model $\mathrm{C} / \mathrm{S} / \mathrm{T}$ but significant cointegration in model $\mathrm{C} / \mathrm{T}$. Models $\mathrm{C} / \mathrm{S} / \mathrm{T}$ and model $\mathrm{C} / \mathrm{T}$ are estimated.

The long run parameters of the two models are estimated using OLS. The results are presented in Table 13. The estimates of the models seem to imply that Model $\mathrm{C} / \mathrm{T}$ is the only plausible model since more estimated coefficients of the explanatory variables are significant. The residuals from Model C/T are used to estimate the short run dynamic equation for the determinants of service sector productivity growth with the error-correction adjustment model (ECM).

In model $\mathrm{C} / \mathrm{T}$, Agriculture sector productivity grow by about $23.6 \%$, when investment increases by $1 \%$, it however decreased by $2.2 \%$, about $41.2 \%$ and about $48.96 \%$ (though insignificant) when Banking sector Liberalization, Capital account openness and Trade liberalization) increase by $1 \%$ respectively in the long run. This results also rejects the assumption that there is no long-run effect of financial liberalization on productivity growth of economic sectors in Ghana.

Table 12. Estimated long run coefficients of Models C; Model C/T; Model C/S and Model C/S/T) Cointegration equations 1970-2013 (Agriculture Sector Value Added)

\begin{tabular}{lllll}
\hline Variables & $\begin{array}{l}\text { Model C } \\
\text { (DUM1981) }\end{array}$ & $\begin{array}{l}\text { Model C/T } \\
\text { (DUM1981) }\end{array}$ & $\begin{array}{l}\text { Model C/S } \\
\text { (DUM1979) }\end{array}$ & $\begin{array}{l}\text { Model-C/S/T } \\
(\text { DUM1981) }\end{array}$ \\
\hline Constant & $-8.071(0.362)$ & $-1.134(0.894)$ & $0.909(0.983)$ & $-1.138(0.894)$ \\
Dum Xcon. & $3.485(0.142)$ & $4.503\left(0.045^{* *}\right)$ & $8.733(0.240)$ & $4.503\left(0.046^{* *}\right)$ \\
Trend & n.a & $-0.112\left(0.009^{* * *}\right)$ & n.a & $-0.112(0.009 * * *)$ \\
LnTLIB & $4.809\left(0.008^{* * *)}\right.$ & $(4.920(0.003 * * *)$ & $-1.9234(0.827)$ & $\left(4.920\left(0.0034^{* * *}\right)\right.$ \\
LnBSLIB & $-1.374(0.362)$ & $-0.623(0.565)$ & $-5.0675(0.367)$ & $-0.623(0.565)$ \\
lnCAOPN & $1.167(0.776)$ & $-3.438(0.407)$ & $33.577(0.089 *)$ & $-3.438(0.407)$ \\
lnSLINV & $-2.663(0.776)$ & $-1.128(0.527)$ & $-6.118(0.518)$ & $-1.128(0.527)$ \\
\hline R-squared & 0.085 & 0.394 & 0.296 & 0.394 \\
Adj. R-sq & -0.035 & 0.292 & 0.203 & 0.292 \\
\hline
\end{tabular}

Source: Author's computation.

\subsection{OLS, Using Observations 1970-2013 (T = 44) Dependent Variable: $\ln A S P$}

The results of short-run dynamic equilibrium relationship coefficients estimated are reported in Table 13. All the 
explanatory variables in the model are significant with the exception of Capital account openness. The error correction term (ECM) -0.957667 is statistically significant and has the expected theoretical sign of negative. The implication is that in the short-run financial liberalization influences the productivity growth of the agriculture sector in Ghana. The coefficient of -0.957667indicates that 1 percent deviation or shock to system will bring about the long-run equilibrium relationship of agriculture sector productivity growth to quickly re-establish at the rate of 95.77 percent per annum indicating a strong adjustment rate.

Table 13. Short run coefficient estimates

\begin{tabular}{lllll}
\hline Model C/S & Regresand $=\ln A S P$ & & \\
Regressors & Elasticities & Std Error & T-ratio & P-value \\
\hline d_lnASP_1 & -0.022 & 0.0085 & -2.822 & $0.008 * * *$ \\
Constant & 1.854 & 0.0303 & 61.49 & $1.92 \mathrm{e}-036 * * *$ \\
lnBSLIB & -0.0223 & $0.089 \mathrm{I}$ & 2.766 & 0.009 *** \\
lnTLIB & -0.4121 & 0.1362 & -3.025 & 0.005 \\
lnCAOP & -0.4891 & 0.3081 & -1.586 & 0.122 \\
lnSLINV & 0.2363 & 0.0912 & 126.7 & $4.57 \mathrm{e}-047 * * *$ \\
DUMCON81 & 15.8481 & 0.1252 & 126.7 & $4.57 \mathrm{e}-047 * * *$ \\
EC1 & -0.9582 & 0.0114 & -87.32 & $1.38 \mathrm{e}-041 * * *$ \\
\hline Mean dependent var & -0.0184 & S.D. dependent var & & 3.431 \\
Sum squared resid & 0.523 & S.E. of regression & & 0.124 \\
R-squared & 0.999 & Adjusted R-squared & & 0.999 \\
rho & 0.288 & Durbin-Watson & & 1.289 \\
\hline
\end{tabular}

Source: Author's computation.

\subsection{Stability Test}

The results of the parameter stability test as shown in Figures 1 and Figure 2 indicate that the estimated coefficients are unstable per the CUSUMSQ test. However, the estimated coefficients according to the CUSUM showed stability as the residuals fall within the $5 \%$ critical boundaries.

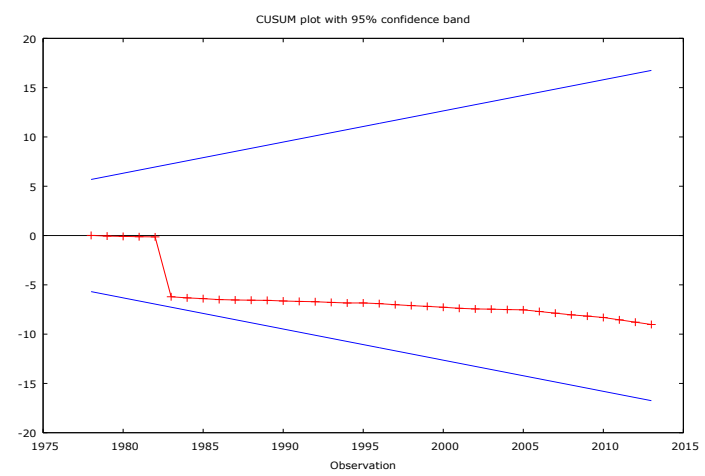

Figure 1. Plot of CUSUM (ASP)

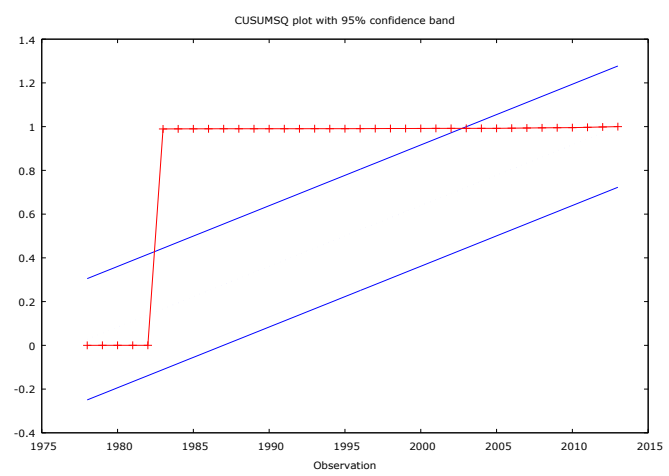

Figure 2. Plot of CUSUMSQ (ASP)

\subsection{Long-Run Effects of Financial Liberalization}

The results of the long run parameter estimates of the multivariate productivity growth model using the Gregory-Hanson model has established that there is long-run relationship between financial liberalization and productivity growth of agriculture sector

The error correction term is significant in Agriculture sector productivity growth confirming the long run stable relationship in the estimated models for Agriculture sector productivity growths. The findings of the study provide enough grounds to reject the first null hypothesis (Ho) that there is no long-run effect of financial liberalization on productivity growth of agriculture sector in Ghana and to accept the alternative hypothesis (H1) that there is long-run effect of financial liberalization on productivity growth of agriculture sector in Ghana.

In the long-run, the results show that trade liberalization is a significant determinant of Agriculture sector 
productivity. Trade liberalization has the expected a priori theoretical sign of positive. The results show that $1 \%$ increase in trade liberalization leads to about $492 \%$ increase in Agriculture sector productivity growth (at 5\%).

The study revealed that investment is a significant determinant of Agriculture sector productivity growth in the short run. Investment has the expected a priori theoretical sign of positive in Agriculture sector productivity growth. The results show that $1 \%$ increase in investment leads to about $23.56 \%$ increase in Agriculture sector productivity growth (at $1 \%$ ).

\subsection{Short-Run Effects of Financial Liberalization}

Banking sector liberalization and Trade liberalization negatively influence agriculture sector productivity growth in the short run. Consistent with this finding is the reports by Djokoto (2013) and Karikari (1992) for Ghana. The findings are however not consistent with the findings from previous studies such as Hassine, Robichaud and Decaluwe (2010), Andersen and Babula (2008) and Nirodha, Malaga and Johnson (2013) who reported that opening up of foreign trade promotes productivity growth under the agricultural trade liberalization scheme. The coefficient of Capital account openness has unexpected a priori theoretical sign of negative instead of positive in the Agriculture productivity growth model. Also, in the short-run, capital account openness is not a significant determinant of the sector's productivity growth. The coefficient of Capital account openness has unexpected a priori theoretical sign of negative instead of positive in the Agriculture sector productivity growth model.

\subsection{Effects of External Shock to Financial Liberalization on Productivity Growth}

The findings of the study indicate that, there is permanent effect of shock to financial liberalization and productivity growth of the Agriculture Sector in Ghana. The study also shows that, there are structural breaks that coincide with identified climatic, economic, and political shocks in Ghana. For example in 1983, there was drought in Ghana, which affected crop production and electricity generation from the Akosombo dam and total energy generation and use by firms and industries in the country. These findings are in support of Dramani et al. (2012) for Ghana. The theoretical implications are that, the theories of structural breaks are supported, and that anticipated values of real output that do not take account of structural breaks might present errors, and therefore may not be reliable in any economic developmental policies.

\section{Conclusion}

The study investigated the effects of financial liberalization on productivity growth of the Agricultural sector as measured by total factor productivity (TFP) in the presence of structural breaks. Findings of the study shows that Trade Liberalization is the only significant determinant of agriculture sector productivity growth in the long run. Proponents of trade theory maintain that free trade increases welfare. This notwithstanding, the welfare effects of free trade have been contested by several studies. While some show that there is little or no evidence to suggest that trade liberalization involves accelerating agricultural productivity growth or per capita income, there is however, a significant level of empirical evidence confirming that there is a link between trade openness and productivity growth which results from trade liberalization. This finding is in agreement with previous studies such as Andersen and Babula (2008), Fauzel (2012), Borchert and others (2010); Arnold and others (2012); and Fernandes and Paunov (2012).

In the short run, the key variable that influences agriculture sector productivity growth is investment, confirming the findings of the study carried out by Demeulemeester and Hottenrott, (2015) and Brown et al. (2012). The theoretical preposition that developing economies are closed economies with limited access to external finance and self-finance investments is confirmed; the implication is that alleviating financial restrictions in developing economies will lead to competitive market equilibrium, which will eventually promote efficient allocation of resources to productive sectors for promoting productivity growth in Ghana.

The government and the economic policy makers must ensure that any structural reform program that is initiated is comprehensively and completely implemented and also accompanied by sound macroeconomic policies to maintained a lasting effect, because the effect of such structural reforms in the long run growth path are prone to be thrown out of gear by other external shocks if not taken into consideration.

Theoretically, productivity growth model is confirmed in Ghana. Expansionary fiscal policy is therefore supported as against contractionary policy. In Practice opening up trade and improving the financial sector will improve productivity growth of the agriculture sector in Ghana.

Future studies could be focused on whether financial liberalization will yield the expected effect on agriculture and other economic sectors' productivity growth using primary data from the various sectors of the economy in a survey study. 


\section{References}

Abiad, A., Oomes, N., \& Ueda, K. (2008). The quality effect: Does financial liberalization improve the allocation of capital? Journal of Development Economics, 87(2). https://doi.org/10.1016/j.jdeveco.2007.12.002

Acemoglu, D., Aghion, P., \& Zilibotti. F. (2006). Distance to Frontier, Selection, and Economic Growth. Journal of the European Economic Association, 4(1), 37-74. https://doi.org/10.1162/jeea.2006.4.1.37

Acemoglu, D., Johnson, S., \& Robinson, J. A. (2005). Institutions as a Fundamental Cause of Long-Run Growth. Handbook of Economic Growth, 1(1), 385-472. https://doi.org/10.3386/w10481

Ackah, C., Aryeetey, E., \& Morrissey, O. (2012). Tariffs and Total Factor Productivity: The Case of Ghanaian Manufacturing Firms. Modern Economy, 3(3), 275-283. https://doi.org/10.4236/me.2012.33037

Ackerberg, D., Benkard, C. L., Berry, S. \& Pakes, A. (2007). Econometric tools for analyzing market outcomes. In J. Heckman, \& E. Leamer (Eds.), Handbook of Econometrics, 6(1), 4171-4276. Amsterdam: North-Holland. https://doi.org/10.1016/S1573-4412 (07) 06063-1

Agbaeze, E. K., \& Onwuka, I. O. (2014). Financial liberalization and investments - the Nigeria Experience. Journal of Research in Economics and International Finance (JREIF), 3(1), 12-24.

Ahiakpor, F., \& Dasmani, I. (2012). Access to Finance and Efficiency of Firms in Ghana. Draft report, University of Cape Coast.

Ajao, A. O. (2011). Empirical analysis of agricultural productivity growth in Sub-Sahara Africa: 1961-2003. Libyan Agricultural Resource Center Journal International, 2(5), 224-231.

Akinlo, A. E. (2005). Impact of Macroeconomic Factors on Total Factor Productivity in Sub-Saharan African Countries. World Institute for Development Economics Research, Research Paper No. 2005/09.

Akpaeti, A. J. (2015). Impact of Financial Sector Reforms on Agricultural Growth in Nigeria: A Vector Autoregressive (Var) Approach. American Journal of Experimental Agriculture, 7(1), 17-35. https://doi.org/10.9734/AJEA/2015/11423

Ali, N., \& Najman, B. (2015). Informal Competition and Productivity in Sub-Saharan Africa. Draft of University of Paris, France.

Andersen, L., \& Babula, R. (2008). The link between openness and long-run economic growth. Retrieved from http://www.usitc.gov/publications/332/journals/openness_growth_link.pdf

Arnold, J., Javorcik, B., Lipscomb, M., \& Mattoo, A. (2012). Services Reform and Manufacturing Performance: Evidence from India. WB Policy Research Working Paper 5948, World Bank, Washington. https://doi.org/10.1596/1813-9450-5948

Baumann, S., Hermes, N., \& Lensink, R. (2013). Financial liberalization and economic growth: A meta-analysis. Journal of International Money and Finance, 33(3), 255-281. https://doi.org/10.4324/9780203714287

Beck, T., Levine, R., \& Loayza, N. (2000). Finance and the sources of growth. Journal of Financial conomics, 58(2), 261-300. https://doi.org/10.1596/1813-9450-2057

Bekaert, G., Harvey, C. R., \& Lundblad, C. (2011). Financial openness and productivity. World Development, 39(1), 1-19. https://doi.org/10.2139/ssrn.1358574

Bencivenga, V., \& Smith, B. (1991). Financial intermediation and endogenous growth. Review of Economic Studies, 58(2), 195-209. https://doi.org/10.2307/2297964

Benhabib, J., \& Spiegel, M. M. (2000). The role of financial development in growth. Journal of Economic Growth, 5(4), 341-360. https://doi.org/10.1023/A:1026599402490

Biatour, B., Dumont, M., \& Kegels, C. (2011). The determinants of industry-level total factor productivity in Belgium. Federal Planning Bureau working paper 7-11.

Borchert, I., Gootiiz, B., \& Mattoo, A. (2010). Restrictions on Services Trade and FDI in Developing Countries. World Bank, mimeo.

Borensztein, E., De Gregorio, J., \& Lee, J. W. (1998). How does foreign direct investment affect economic growth? Journal of International Economics, 45(1), 115-35. https://doi.org/10.1016/S0022-1996 (97) 00033-0

Chauvet, L., \& Jacolin, L. (2015). Financial Inclusion and Firms Performance. Seminar paper.

Chen, M., \& Guariglia, A. (2011). Financial Constraints and firm productivity in China: Do liquidity and export 
behaviour make a difference? Research paper series, China and the World Economy, University of Nottingham. https://doi.org/10.2139/ssrn.1863864

Chipeta, C. (2012). Financial Liberalization and the Capital Structure of Firms Listed on the Johannesburg Stock Exchange. Retrieved from http://www.repository.up.ac.za/bitstream/handle/2263/23951

Christiansen, L., Schindler, M., \& Tressel, T. (2013). Growth and Structural Reforms: A New Assessment. Journal of International Economics, 89(2), 347-56. https://doi.org/10.1016/j.jinteco.2012.07.008

Clemente, J., Montañés, A., \& Reyes, M. (1998). Testing for a unit root in variables with a double change in the mean. Economics Letters, 59(2), 175-182. https://doi.org/10.1016/j.econlet.2019.06.003

Cobb, C. W., \& Douglas, P. H. (1928). A Theory of Production. American Economic Review, 18(1), 139-165. Retrieved from http://www.econ.iastate.edu/classes/econ521/Orazem/Papers/cobb-douglas

Dabla-Norris, E., Giang, H. Kalpana, K., Annette, K., \& Robert, T. (2013). Anchoring Growth: The Importance of Productivity-Enhancing Reforms in Emerging Market and Developing Economies. IMF Staff Discussion Note 13/08, Washington: International Monetary Fund. https://doi.org/10.5089/9781498334181.006

Dabla-Norris, E., Giang, H., \& Kobe, A. (2013). Reforms and Distance to Frontier. IMF Technical Note to Staff Discussion Note 13/08. Washington: International Monetary Fund.

Dabla-Norris, E., Guo, S., Haksar, V., Kim, M. K., Kochhar, K. W., \& Zdzienicka. A. (2015). The New Normal: A Sector-Level Perspective on Growth and Productivity Trends in Advanced Economies. IMF Staff Discussion Note 15/03, International Monetary Fund, Washington. https://doi.org/10.5089/9781498334181.006

Didier, T., \& Schmukler. S. L. (2014). Financial Development in Asia: Beyond Aggregate Indicators. https://doi.org/10.1596/1813-9450-6761

Djokoto, J. G. (2013). Openness and Agricultural Performance in Ghana. Journal of Science and Technology, 33(2), 24-36. https://doi.org/10.4314/just.v33i2.3

Dramani, J. B., Tandoh, F., \& Tewari, D. D. (2012). Structural breaks, electricity consumption and economic growth: Evidence from Ghana. African Journal of Business Management, 6(22), 6709-6720. https://doi.org/10.5897/AJBM11.2800

Du, J., \& Girma, S. (2012). Firm Size, Source of Finance, and Growth - Evidence from China. International Journal of the Economics of Business, 19(3), 397-419. https://doi.org/10.1080/13571516.2012.715272

Effiong, E. (2015). Financial Development, Institutions and Economic Growth: Evidence from Sub-Saharan Africa.

ESSO, L. J. (2009). Cointegration and causality between financial development and economic growth: Evidence from ECOWAS countries. European Journal of Economics, Finance and Administrative Sciences, 16(1), $112-122$.

Fernandez-Arias, E., \& Montiel, P. J. (1996). The surge in capital inflows to developing countries: An analytical overview. World Bank Economic Review, 10(1), 51-77. https://doi.org/10.1093/wber/10.1.51

Fischer, M. (2010). Generalized tukey-type distributions with application to financial and teletraffic data. Stat Papers, 51(1), 41-56. https://doi.org/10.1007/s00362-007-0114-z

Fons-Rosen, C., Kalemli-Ozcan, S., Sørensen, B. E., Villegas-Sanchez, C., \& Volosovych, V. (2013). Quantifying Productivity Gains from Foreign Investment. NBER Working Paper no. 1892. https://doi.org/10.3386/w18920

Fowowe, B. (2004). Financial Liberalization Policies and Economic Growth: Panel Data Evidence from Sub-Saharan Africa. Paper presented at the CSAE conference, Oxford, 21-22.

Gatti, R., \& Love, I. (2008). Does access to credit improve productivity? Evidence from Bulgaria. Economics of Transition, 16(3), 445-465. https://doi.org/10.1111/j.1468-0351.2008.00328.x

Gehringer, A. (2013a). Growth, Productivity and Capital Accumulation: The Effects of Financial Liberalization in the Case Of European Integration. Int. Rev. Econ. Finance, 25(3), 291-309. https://doi.org/10.2139/ssrn.2024887

Gehringer, A. (2013b). Financial liberalization and productivity growth in manufacturing and service sectors: Evidence from panel investigation on sector-level data. Retrieved from http://www.economics-ejournal.org/economics/discussionpapers 
Gehringer, A. (2014a). Uneven Effects of Financial Liberalization on Productivity Growth in the EU: Evidence from a dynamic panel investigation. International Journal of Production Economics, 159(3), 334-346. https://doi.org/10.1016/j.ijpe.2014.05.003

Goedhuys, H., Janz, N., \& Mohnen, P. (2006). What drives Productivity in Tanzanian Manufacturing Firms: Technonogy or Institutions? Working Paper.

Goldsmith, R. W. (1969). Financial Structure and Development. New Haven, CT: Yale University Press.

Granger, C. J. (1969). Investigating Causal Relationships by Econometrics Models and Cross Spectral Methods. Econometrica, 34(3), 424-438. https://doi.org/10.2307/1912791

Greenwood, J., \& Jovanovic, B. (1990). Financial development, growth, and the distribution of income. Journal of Political Economy, 98(5), 1076-1107. https://doi.org/10.1086/261720

Greenwood, R. \& Scharfstrein, D. (2013). The Growth of Finance. Journal of Economic Perspectives, 27(2), 3-28. https://doi.org/10.1257/jep.27.2.3

Gregory, A. W., \& Hansen, B. E. (1996). Residual-based tests for cointegration in models with regime shifts. Journal of Econometrics, 70(1), 99-126. https://doi.org/10.1016/0304-4076 (69) 41685-7

Gregory, A. W., \& Hansen, B. E. (1996). Tests for cointegration in models with regime and trend shifts. Oxford $\begin{array}{lllll}\text { Bulletin of } & \text { Economics }\end{array}$ https://doi.org/10.1111/j.1468-0084.1996.mp58003008.x

Grilli, V., \& Milesi-Ferretti, G. M. (1995). Structural Determinants and Economic Effects of Capital Controls. International Monetary Fund Staff Papers.

Gujarati, D. N. (2004). Basic Econometrics (4th ed.). McGraw-Hill Companies.

Hall, R. E., \& Jones, C. I. (1999). Why do some countries produce so much more output per worker than others? Quarterly Journal of Economics, 114(1), 83-116. https://doi.org/10.1162/003355399555954

Henry, P. B. (2000). Stock market liberalization, economic reform, and emerging market equity prices. Journal of Finance, 55(2), 529-564. https://doi.org/10.1111/0022-1082.00219

Hoskins, C. N., \& Mariano, C. (2004). Research in Nursing and Health: Understanding and Using Quantitative and Qualitative Methods (2nd ed.). New York, CA: Springer Publishing Company.

IFC. (2013). World Bank Group. Retrieved from https://openknowledge.worldbank.org/handle/10986/15772

Jedwab, R., \& Osei, D. R. (2012). Structural change in Ghana 1960-2010. Retrieved from https://www2.gwu.edu/ iiep/assets/docs/papers/Jedwab_IIEPWP2012-12.pd

Karikari, J. A. (1992). Causality between Direct Foreign Investment and Economic Output in Ghana. Journal of Economic Development, 17(1), 7-17.

King, R. G., \& Levine, R. (1993a). Finance and growth: Schumpeter might be right. Quarterly Journal of Economics, 108(3), 717-737. https://doi.org/10.2307/2118406

King, R. G., \& Levine, R. (1993b). Finance, entrepreneurship, and growth: theory and evidence. Journal of Monetary Economics, 32(3), 513-542. https://doi.org/10.1016/0304-3932 (93)90028-E

Kose, A. M., Prasad, E. S., \& Terrones, M. E. (2009). Does openness to international financial flows raise productivity growth? Journal of International Money and Finance, 28(4), 554-580. https://doi.org/10.1016/j.jimonfin.2009.01.005

Krishnan, K., Nandy, D. K., \& Puri, M. (2014). Does Financing Spur Small Business Productivity? Evidence from a Natural Experiment. The Review of Financial Studies, 28(6). https://doi.org/10.1093/rfs/hhu087

Lane, P. R., \& Milesi-Feretti, G. M. (2001). The external wealth of nations: Measures of foreign assets and liabilities for industrial and developing countries. Journal of International Economics, 55(2), 263-294. https://doi.org/10.1016/S0022-1996 (01)00102-7

Lane, P. R., \& Milesi-Feretti, G. M. (2007). The external wealth of nations mark II: Revised and extended estimates of foreign assets and liabilities, 1970-2004. Journal of International Economics, 73(2), 223-250. https://doi.org/10.1016/j.jinteco.2007.02.003

Larrain, M., \& Stumpner, S. (2013). Financial Reforms and Aggregate Productivity: The Microeconomic Channel. Working Paper. https://doi.org/10.2139/ssrn.2172349

Levine, O., \& Warusawitharana, M. (2014). Finance and productivity growth: Firm-level evidence. Finance and 
Economics discussion series. Division of research \& Statistics and Monetary affairs Federal Reserve Board, Washington, D.C. https://doi.org/10.17016/FEDS.2014.17

Levine, R. (1996a). Foreign banks, financial development, and economic growth. In C. E. Barfield (Ed.), International financial markets. Washington DC. CA: Enterprise Institute Press:

Levine, R. (1997b). Financial development and economic growth: Views and agenda. Journal of Economic Literature, 35(2), 688-726.

Levine, R. (2005a). Finance and Growth: Theory and Evidence. In P. Aghion, \& S. N. Durlauf (Eds.), Handbook of Economic Growth. Elsevier North Holland.

Maurel, M., \& Seghir, M. (2014). The main obstacles to firm's growth in Senegal, implications for the long run. African Development Bank Group Working Paper Series, 208. https://doi.org/10.35188/UNU-WIDER/2014/880-3

Midrigan, V., \& Xu, D. Y. (2014). Finance and Misallocation: Evidence from Plant-Level Data. American Economic Review, 104(2), 422-58. https://doi.org/10.1257/aer.104.2.422

Nicoletti, G., \& Scarpetta, S. (2003). Regulation, Productivity and Growth: OECD Evidence. Economic Policy, 18(36), 9-72. https://doi.org/10.1111/1468-0327.00102

Nirodha De S., Jaime Malaga, J., \& Johnson, J. (2013). Trade Liberalization Effects on Agricultural Production Growth: The Case of Sri Lanka. Selected Paper Prepared For Presentation at the Southern Agricultural Economics Association Annual (Saea) Meeting, Orlando, Florida, 2-5 February 2013.

OECD (Organization for Economic Cooperation and Development). (2013). The Missing Entrepreneurs. In Policies for Financing, Paris.

Ogunsakin, S. (2014). Nigerian Financial Sector and Manufacturing. IOSR Journal of Applied Chemistry (IOSR-JAC), 7(3), 41-46.

Olanrewaju, H. M. (2016). Implications of Commercial Bank Loans on Economic Growth in Nigeria (1986-2014). Journal of Emerging Trends in Economics and Management Sciences (JETEMS), 7(3), 124-136.

Orji, A., Orji, I. A., \& Nwachukwu, P. (2015). Financial Liberalization and Output Growth in Nigeria: Empirical Evidence from Credit Channel. International Journal of Economics and Financial Issues, 5(1), 297-311

Osei-Assibey, E. (2013). Source of finance and small enterprise's productivity growth in Ghana. African Journal of Economic and Management Studies, 4(3), 372-386. https://doi.org/10.1108/AJEMS-03-2012-0017

Ospina, S., \& Schiffbauer, M. (2010). Competition and firm productivity: Evidence from firm-level data. IMF Working Paper, WP/10/67. https://doi.org/10.5089/9781451982114.001

Patrick, H. T. (1996). Financial development and economic growth in underdeveloped countries. Economic Development and Cultural Change, 14(2), 174-189. https://doi.org/10.1086/450153

Perron, P. (1989). The great crash, the oil Price shock and the unit root hypothesis. Econometrica, 57(6), 1361-1401. https://doi.org/10.2307/1913712

Pesaran M. H., \& Shin, Y. (1999). Econometrics and Economic Theory in the 20th Century: An Autoregressive Distributed Lag Modeling Approach to Cointegration Analysis. Cambridge, UK: Cambridge University Press.

Pesaran, M. H., \& Pesaran, B. (1997). Working with Microfit 4.0: Interactive Econometric Analysis. Oxford, UK: Oxford University Press. https://doi.org/10.1002/jae.616

Pesaran, M. H., Shin, Y., \& Smith, R. J. (2001). Bounds testing approaches to the analysis of level relationships. Journal of Applied Econometrics, 16(3), 289-326. https://doi.org/10.1002/jae.616

Polat, A., Muhammad, S., Ijaz, U. R., \& Saqlain, L. S. (2013). Revisiting Linkages between Financial Development, Trade Openness and Economic Growth in South Africa: Fresh Evidence from Combined Cointegration Test. MPRA Paper No. 51724. http://mpra.ub.uni-muenchen.de/51724/

Prati, A., Onorato, G. M., \& Papageorgiou. C. (2013). Which Reforms Work and under What Institutional Environment? Evidence from a New Data Set on Structural Reforms. Review of Economics and Statistics, 95(3), 946-68. https://doi.org/10.1162/REST_a_00307

Rajan, R., \& Zingales, L. (2001). Financial Systems, Industrial Structure, and Growth. Oxford Review of 
Economic Policy, 17(4), 467-82. https://doi.org/10.1093/oxrep/17.4.467

Rajan, R., \& Zingales, L. (2003). The great reversals: the politics of financial development in the twentieth century. Journal of Financial Economics, 69(1), 5-50. https://doi.org/10.1016/S0304-405X (03)00125-9

Richardson, K. E., \& Tamarauntari, M. K. (2014). Economic Liberalization and Industrial Sector Performance in Nigeria- A Marginal Impact Analysis. Industries International Journal of Development and Emerging Economics, 2(4), 43-59,

Saint-Paul, G. (1992). Technological choice, financial markets and economic development. European Economic Review, 36(4), 763-781. https://doi.org/10.1016/0014-2921 (92)90056-3

Saliola, F., \& Seker, M. (2011). Total Factor Productivity across the developing world. World Bank Group, Enterprise Note Series No. 23.

Schmukler, S. L. (2003). Financial globalization: gains and pain for developing countries. Word Bank, Washington, DC.

Schumpeter, J. A. (1911). The Theory of Economic Development. Cambridge, MA: Harvard University Press.

Schumpeter, J. A. (1912). Theorie der wirtschaftlichen Entwicklung. Leipzig: Duncker \& Humblot.

Shaw, E. S. (1973). Financial Deepening in Economic Development. London, UK: Oxford University Press,

Solow, R. M. (1956). A Contribution to the Theory of Economic Growth. Quarterly Journal of Economics, 70(1), 65-94. https://doi.org/10.2307/1884513

Solow, R. M. (1963). Capital Theory and the Rate of Return. Amsterdam: North-Holland.

Takii, S. (2005). Productivity Spillovers and Characteristics of Foreign Multinational Plants in Indonesian Manufacturing 1990-1995. Journal of Development Economics, 75(2), 521-542. https://doi.org/10.1016/j.jdeveco.2004.01.006

Tombe, T. (2012). The Missing Good Problem: How Low Agricultural Imports Contribute to International Income and Productivity Differences. Manuscript, University of Calgary.

Udoh, E., \& Ogbuagu, U. R. (2012). Financial Sector Development and Industrial Production in Nigeria (1970-2009): An ARDL Cointegration Approach. Journal of Applied Finance \& Banking, 2(4), 49-68.

World Bank. (2017). Uganda moving beyond recovery: investment and behavior change, for growth country economic memorandum. Report No, 39221-UG.

\section{Copyrights}

Copyright for this article is retained by the author(s), with first publication rights granted to the journal.

This is an open-access article distributed under the terms and conditions of the Creative Commons Attribution license (http://creativecommons.org/licenses/by/4.0/). 